\title{
Possible New Species of Araecerus (Coleoptera: Anthribidae) associated with Mastixiodendronpachyclados (Rubiaceae) of Papua New Guinea
}

\author{
Kari Iamba ${ }^{1}$, Patrick S. Michael ${ }^{2}$, DanarDono ${ }^{3}$, YusupHidayat ${ }^{4}$ \\ ${ }^{1,3,4}$ Departemen Hama danPenyakit, FakultasPertanian, UniversitasPadjadjaran, J1.Raya Bandung Sumedang Km.21, \\ Jatinangor , 45363, Indonesia \\ ${ }^{1}$ New Guinea Binatang Research Center, P O Box 604 , Madang, 511, Papua New Guinea, \\ ${ }^{2}$ Department of Agriculture, PNG University of Technology, Lae, MP 411, Papua New Guinea
}

\begin{abstract}
Araecerus is genus of beetles of the Anthribidae family which are important economic pests of various crops including coffee (Rubiaceae), with A.fasciculatus (Degeer) being the common pest (weevil) of coffee beans. This paper presents a study in which five undescribed species of genus Araecerus were reared predominantly from the seeds of M.pachyclados (Rubiceae), a native tree of Papua New Guinea (PNG). Fruits of M. pachyclados were regularly sampled and insects attacking them were reared, preserved and identified. Fruits were hand collected, photographed, weighed and reared. Insects emerging from the fruits were captured and preserved in 99\% ethanol. All the specimens were identified into morphospecies at the laboratory. The five new species discovered were designated as A. sp.1, A. sp.2, A. sp.3, A. sp.4 and A.sp.5. This was accorded based on differences in body length; scutellum color, size, hair-scales and visibility; length of first and second segments of fore tarsus; apical and subapical teeth-size (mandible and maxillary palpi); declivity of dorsal abdomen; basal-anterior eye markings; lateral eye markings; absence of eye markings; and shape of pygidium. We discovered A. sp.1 has yellowish gold marking inside the base of the eye, A. sp.2 with pygidium almost vertically-flat at abdominal apex, A. sp.3 has eyes without yellowish gold marking and generally dark in color, A. sp. 4 with distinct yellowish gold interior-lateral marking in its eye, and A. sp.5 with pygidium pointed at abdominal apex.
\end{abstract}

Keywords-Araecerus, coleoptera, anthribidae, Mastixiodendronpachyclados, PNG.

\section{INTRODUCTION}

Araecerus is a genus of beetles belonging to the family Anthribidae. They are important storage pests of cash crops such as coffee (Rubiaceae) and cocoa (Malvaceae). The species A. fasciculatus (DeGeer) is a common storage pest of coffee beans (coffee bean weevil) (Barrera 2008). A. fasciculatusis also a common pest infesting cocoa beans in storage (Eduku2014). Duke (1993) mentioned that A. fasciculatus was one of the pest of Nutmeg. A. fasciculatus was reported by Abo and Ja (2014) as major pests of yam and cassava flour. Araeceruslevipennis Jordan is a pest of leguminous plant Leucaenaglauca (L.) that has high protein content that is mainly used as a valuable foraging crop in ranches (Sherman and Tamashiro1955).

Early entomologists like Pascoe (1860) and Jordan (1894) extensively described about one hundred genera and one thousand species under Anthribidae family in which A.Schönherr, (Valentine 2005) was categorized under Subfamily Choraginae and Tribe Araecerini. Choraginae subfamily consisted of 3 species in South America in comparison with 14 species in Central America (Blackwelder1947). Jordan (1907) described ten species while Valentine (1999; 2002) contributed to the revision of the species. At least 98 species of Choraginae existed in the Old World (Mermudes and Lesche, 2014). The first species of the tribe Araecerini is A.fasciculatus (DeGeer1775), a pluralistic species of the genus A.Schoenherr, 1823 that comprises of about 70 described species in Indo Pacific (Mermudes2015).

Ctvrtecka et. al. (2014) obtained 1200 specimens of Anthribidae as a part of Curculionoidea in the same location where our research was carried out, but they could not be reliably identified to species. Seven species were found but had to be excluded also because most of the specimens remain unsorted (Ctvrtecka et. al.2014). Morimoto (1972) described A.Schoenherr as having tarsal segment 3 bilobed, nearly as broad as segment 2; tarsi slender, segments 1 and 2 much longer than wide; front tibiae simple at least in female; front tarsi normal; lateral prothoracic carinae reaching the middle; front tarsal segment 1 longer than the remaining segments added together; and eyes oval, less prominent.

This study was carried out to discover host-specific new species of Araecerus associated with M.pachyclados (Rubiaceae) using its "fallen fruits". 


\section{MATERIALS AND METHODS}

\subsection{Field Sampling}

The study was conducted in relatively a primary forest at Wanang Conservation Area $\left(5^{\circ} 13\right.$ 'S, $145^{\circ} 04$ 'E), Madang, PNG between $15^{\text {th }}$ January to $31^{\text {st }}$ May, 2015. The vegetation of the study area is of mix evergreen rainforest on latosol with a humid climate (Laidlaw et al.2007; Paijmans 1976; Whitfeld et. al.2012). The annual rainfall is $3600 \mathrm{~mm}$, and experiences a mild dry season from July to September, with annual temperature of $26^{\circ} \mathrm{C}$ (McAlpine et. al. 1983; Ctvrteckaet al.2014).

Mastixiodendronpachyclados is a locally abundant fruit bearing tree species, therefore was selected for this study. Fruits were collected (sampled) systematically following rows from within an existing 50 ha forest dynamics plant plot and few were sampled outside the plot. Sampling was carried out in different areas of the forest, including areas of both low and high abundance of $M$. pachyclados. The densities of fruits on the ground were measured and the sampling covered areas of both high and low density of fruits. Fruits of each tree species were separately placed into plastic bags and given an unique tree number code for identification. A fruit from each tree was sliced in half, and photographed together with unsliced fruits.

The fruits were then separated into plastic rearing containers (plastic boxes) and weighed on an electronic balance. Three fruits from each tree were sliced and measured (length, width, height, seed length, seed width and seed height). The rearing containers were closely monitored on a daily basis for hatched insects. The insects which hatched were collected by opening the side of the plastic lid, put in a pre-labeled test tube and preserved in $99 \%$ ethanol.

\subsection{Identification}

All the wet specimens were taken to New Guinea Binatang Research Center (NGBRC) in Madang, PNG to be identified. Identification was carried out with the aid of reference text books, online insect databases (www.buglife.com), and insect database and reference collections of NGBRC. The specimens were initially sorted into morpho-species and given codes based on distinct morphological features. Identification was done to genus level and species were divided into $A$. sp.1, $A$. sp.2, A. sp.3, A. sp.4 and A.sp.5, according to their differences in morphology.

The morphological features used for identification of the 'possible new species' were: body length, tarsal segment, eye markings, apical teeth, scutellum and pygidium. Descriptions of these distinctive morphological features were analyzed using Dichotomous Key System.

\section{RESUltS}

The identification keys of each species and pictures of their specific body parts are presented below.

$>\quad$ Length of body equal to or more than $4 \mathrm{~mm}$ (Figure 1a) and length of body equal to or less than $4 \mathrm{~mm}$ (Figure $1 \mathrm{~b}$ )
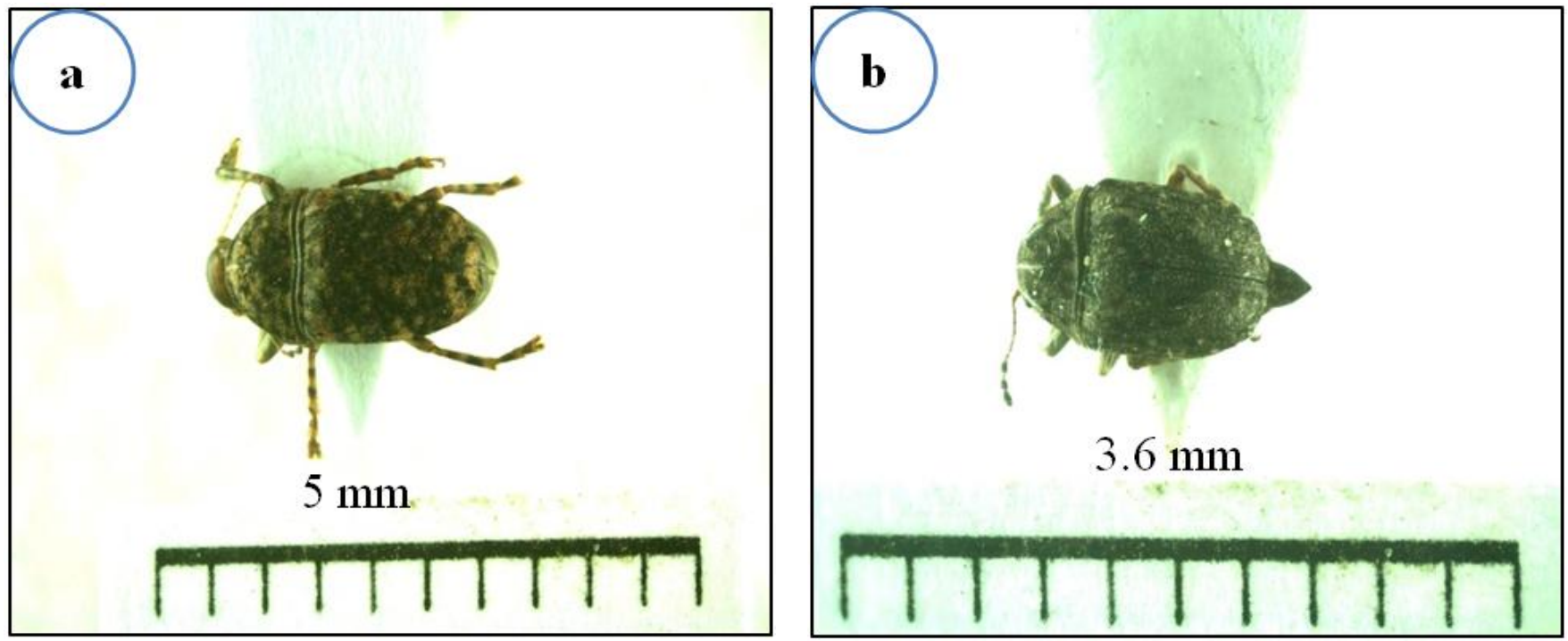

FIG. 1.BODY LENGTH OF THE SPECIES

$>\quad$ Scutellum very small, poorly visible or dark in color (Figure 2a) and scutellum small and densely covered with yellowish brown hair-like scales (Figure 2b). 

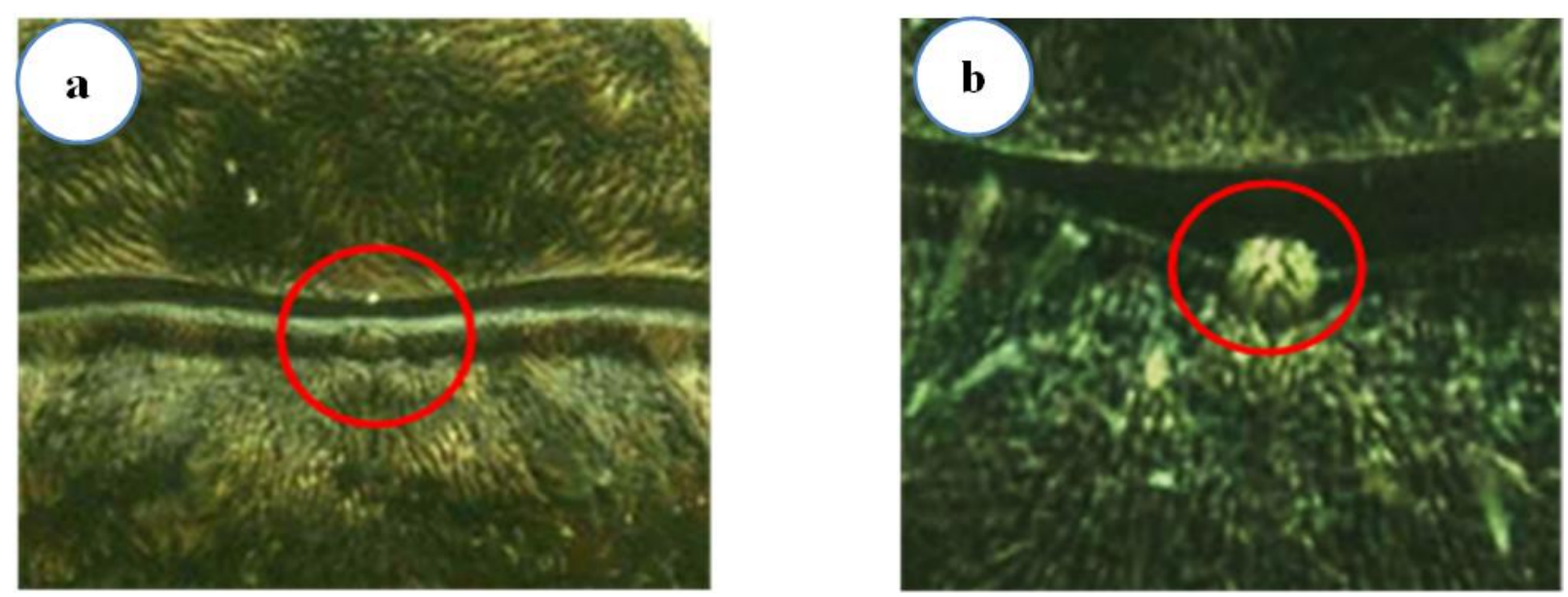

FIG.2.SCUTELLUM SIZE AND COLOR OF THE SPECIES

$>$ First segment of fore tarsus longer than second segment (Figure 3a) and first segment of fore tarsus equal to or shorter than second segment (Figure 3b).
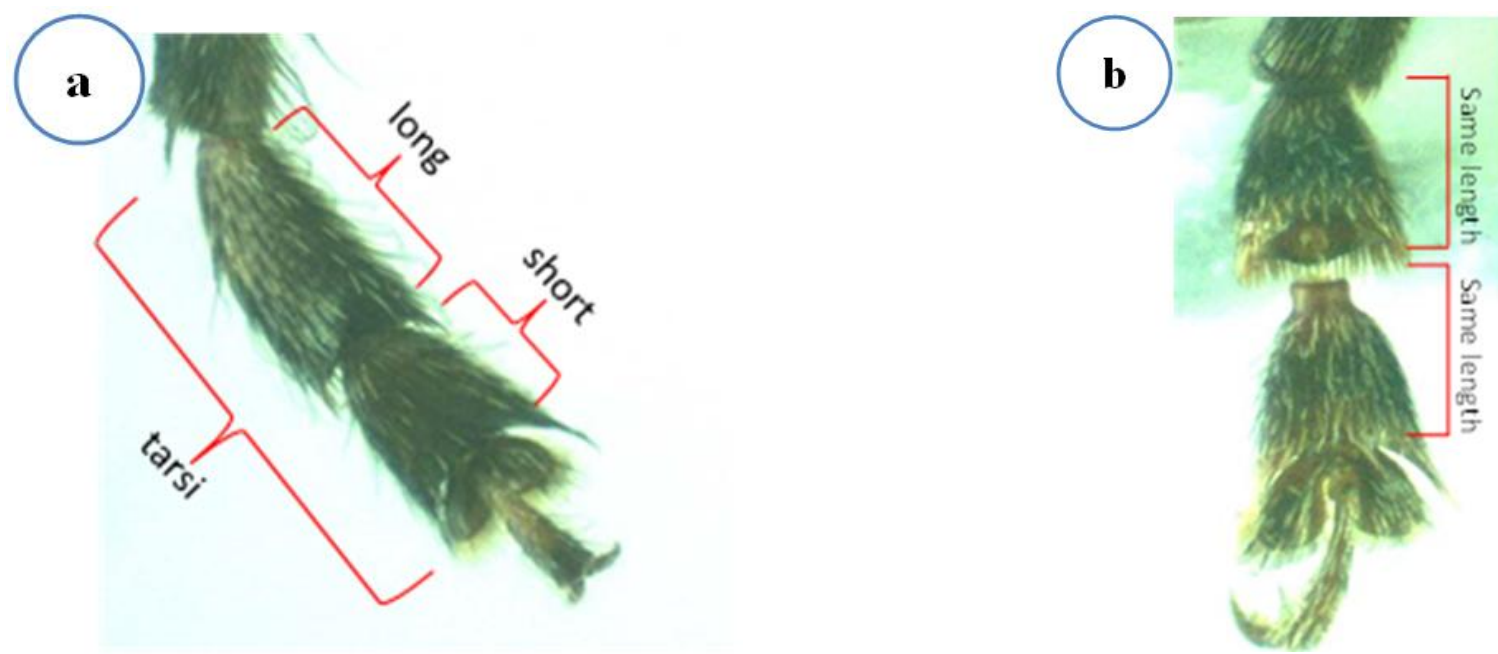

FIG.3.FORE AND SECOND SEGMENT OF TARSUS

$>\quad$ Unequal-sized apical and subapical teeth (mandible and maxillary palpi) (Figure 4a) and almost equal-sized apical subapical teeth (mandible and maxillary palpi) (Figure 4b).
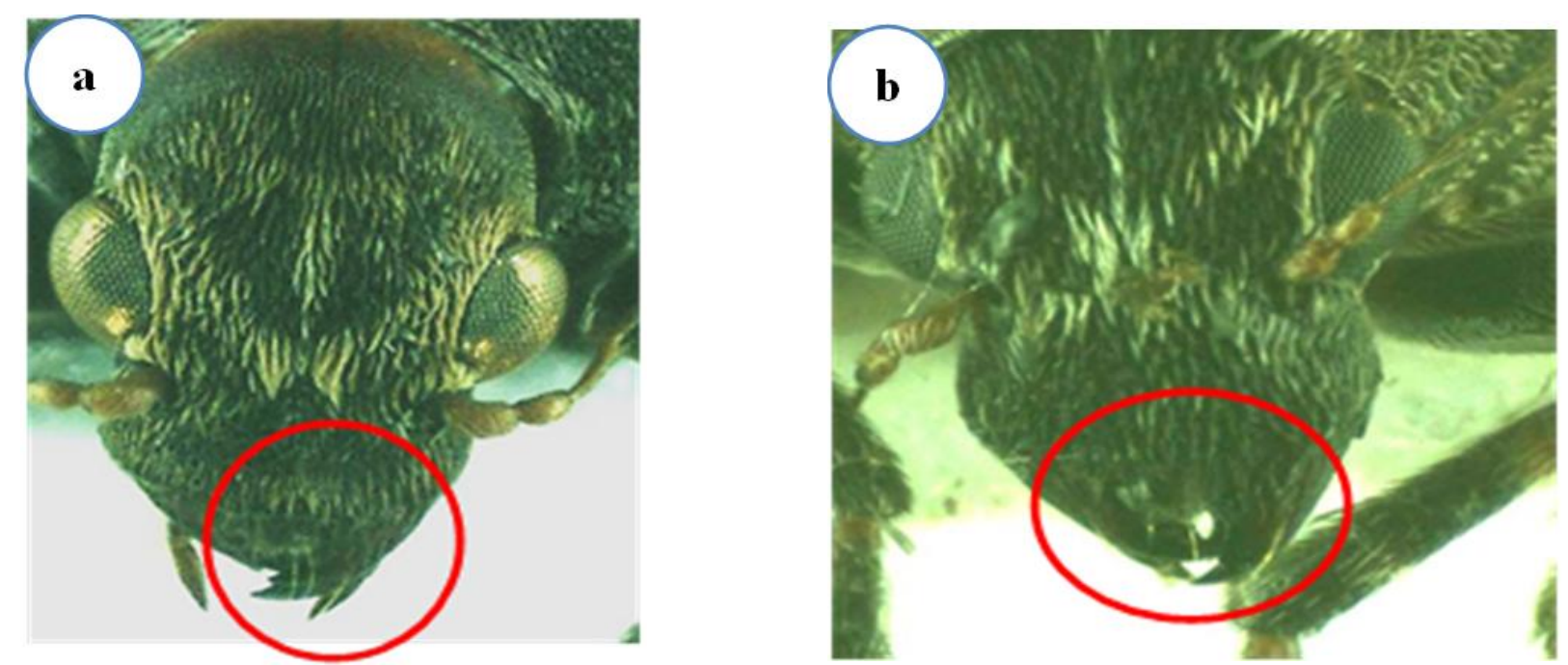

FIG.4.MANDIBLE AND MAXILLARY PALPI OF THE SPECIES 
High declivity towards the abdominal apex (Figure 5a) and low declivity towards the abdominal apex (Figure 5b).
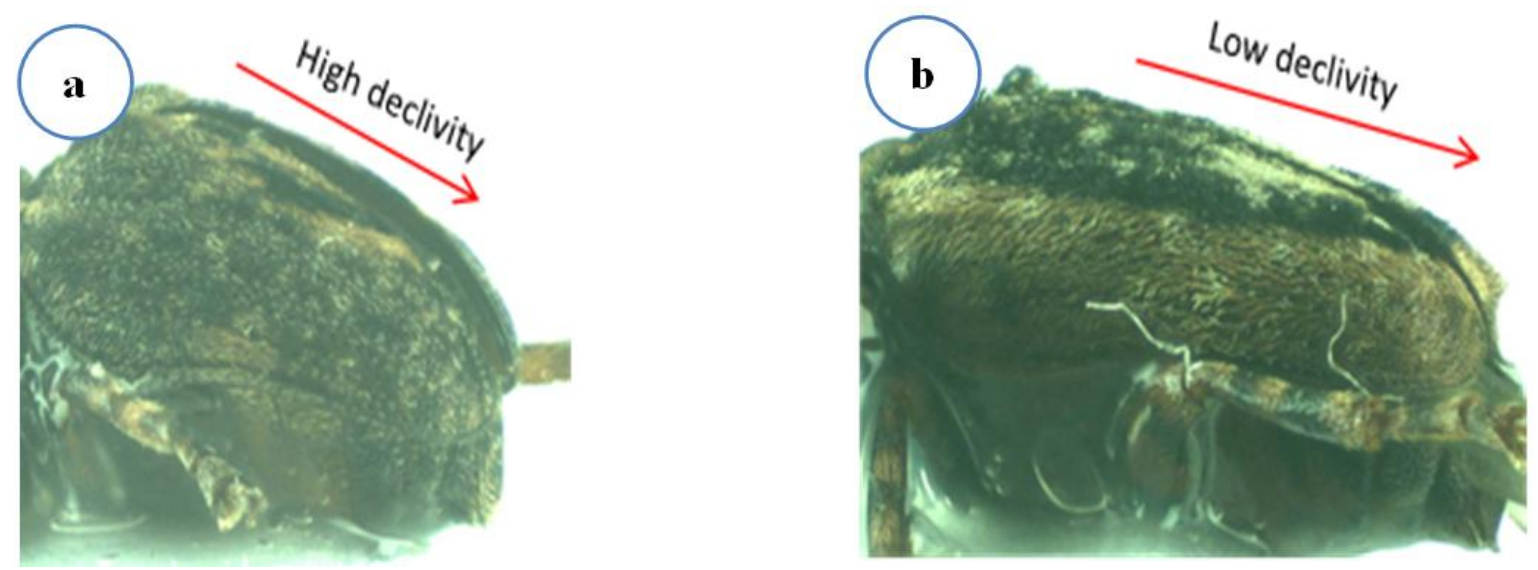

Fig.5. DECLIVITY OF THE SPECIES

Yellowish gold marking inside the base of eye on A. sp. 1(Figure 6a) and eyes without yellowish gold marking inside the base of eye (Figure 6b).
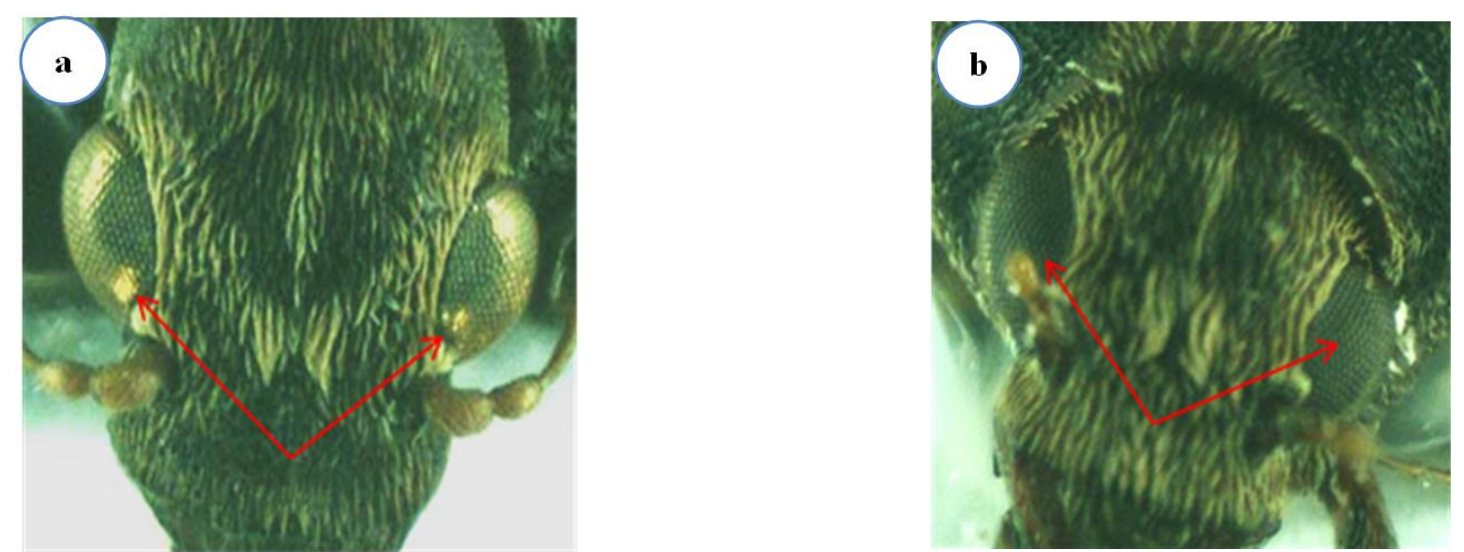

FIG. 6.COLORATION INSIDE THE BASES (6A) SPECIES 1 AND (6B) SPECIES

$>\quad$ Pygidium pointed at abdominal apex in A. sp. 5 (Figure 7a) and pygidium almost vertically-flat at abdominal apex in A. sp. 2 (Figure 7b).
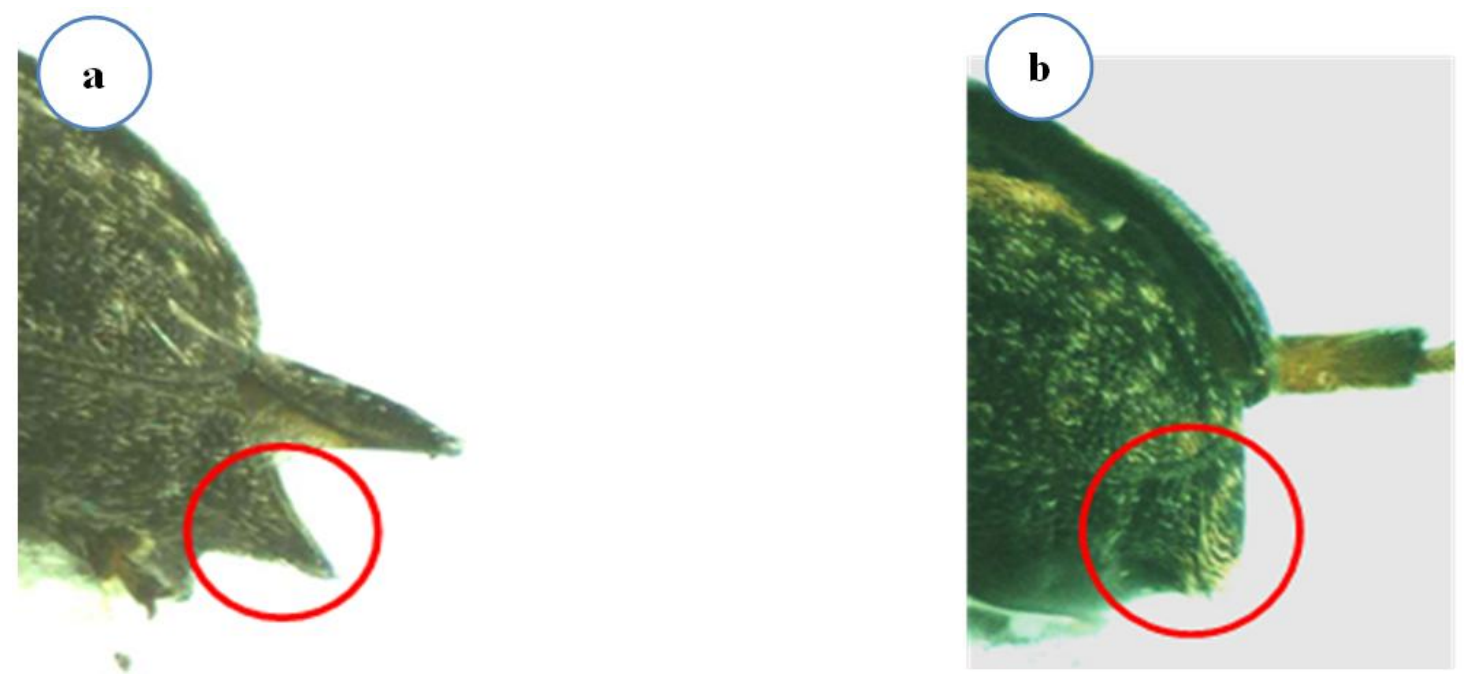

FIG.7.PYGIDIUM ORIENTATION (7A) SPECIES 5 AND (7B) SPECIES 2 
Eye with yellowish gold interior-lateral marking in A.sp. 4 (Figure 8a) and eye without marking and generally dark in color of A.sp. 3 (Figure 8b).
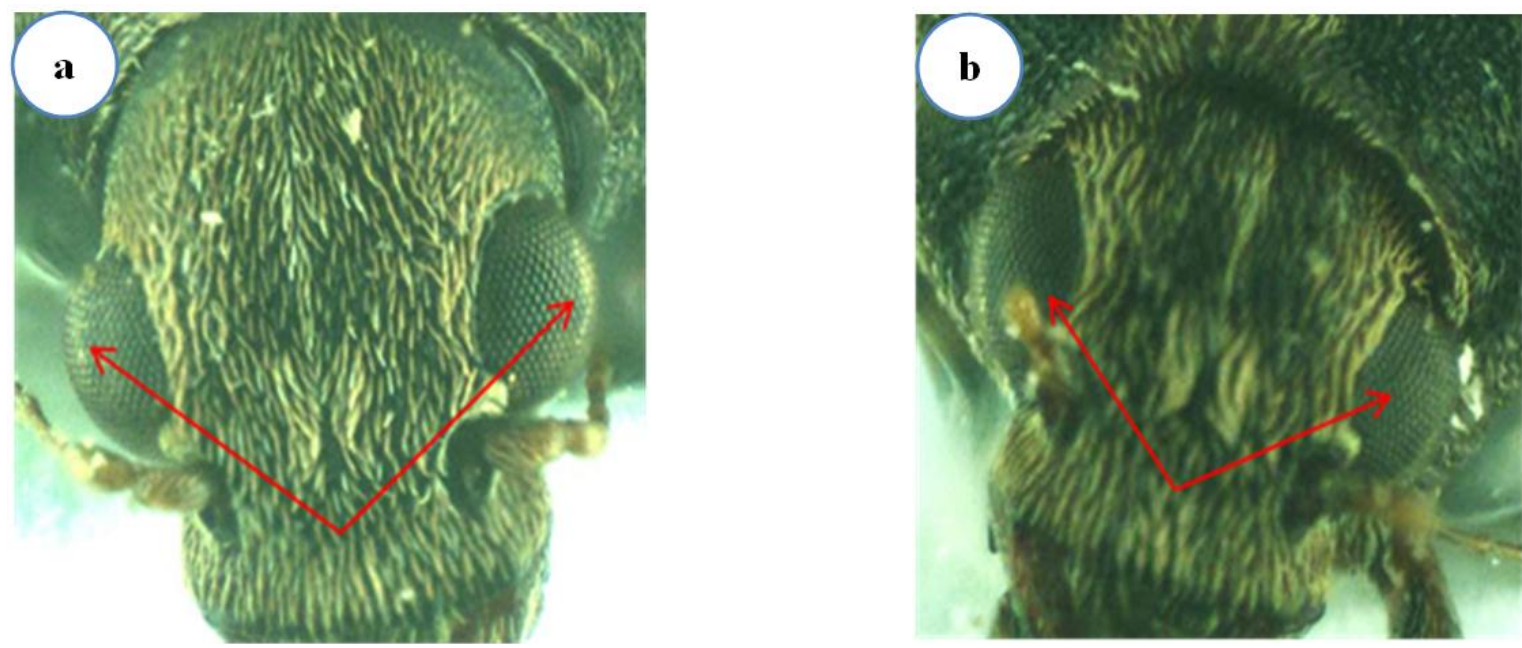

FIG.8.INTERIOR LATERAL MARKING (8A) SPECIES 4 AND (8B) SPECIES 3

\section{DISCUSSION}

Araecerus belonging to the Anthribidae family has the prominent club shaped antenna; adults are elongated and slightly oval; have a short beak and straight antennae; elytra with distinct rows of striae absent; and pronotum with a transverse ridge towards the base. As per Holloway (1982), the genus Araecerus has (i) second segment of tarsi forming lobes around the third segment; (ii) elytra with areas of differently colored scale-like hairs; (iii) antenna attached on the top of the head; (iv) base of antennal segment and groove is visible from above; (v) first segment of the tarsi is three times longer than wide; (vi) pronotum without a transverse ridge but with the base itself slightly raised; and (vii) base of pronotum gently curved with mid part converging towards scutellum.

The five species identified differ from their close relative A. fasciculatus by certain morphological features. A. fasciculatus possess antennal club, and the entire eye and the elytra without distinct striation (Bright 1993). Body length of an adult beetle is about 3-5 mm (El-sayed 1935; Bright 1993; Robinson 2005). All the five species identified fall in the same body length range; A.sp.1 (5mm), A. sp.2 (3.8 mm), A. sp.3 (4mm), A. sp.4 (4.5mm) and A.sp.5 (3.6mm). In comparison to the five species, A. fasciculatus has paler elytra with hairs denser and irregular so that there are darker and lighter areas and the first segment of the front tarsi is as long as the rest of the segments combined (including the claws). The five species have dense hairs, regular markings on the elytra and first segment of the front tarsi shorter than the rest of the segments combined (including the claws).

Interestingly, all species identified are host-specific to M.pachyclados and predominantly reared from seeds rather than the mesocarp. Since coffee (Coffeaarabica \& C. robusta) belongs to the same family as M. pachyclados, this unique feeding guild thus categorizes the five "new possible species"as seed feeders. Species under Araecerus,e.g. A.fasciculatus, mostly are reported as seed feeds of important crops such as coffee (Barrera 2008), cocoa (Eduku 2014), nutmeg (Duke 1993), leguminous plant Leucaenaglauca L.) (Sherman and Tamashiro 1955) and on pesticide plant, Meliaazedarach L. (Ardakani and Nasserzadeh 2014). These indicate that the outcome of this study has implications for management of the species identified.

The fact that the insects were reared from M.pachyclados in a tropical rainforest habitat demonstrates wide host range of Araecerus beetles, and a range of forest trees as alternate host for breeding, oviposition, migration and food resources. We propose additional studies on molecular characterization and analysis for confirmation of these species.

\section{CONCLUSION}

The genus Araecerus is a major pest of important cash crops (e.g. coffee and cocoa) and identification of new pests and quantification of their abundance are prerequisites to crop protection. It is known now that A. fasciculatus was found feeding on pesticide plant Meliaazedarach L., which may support their ability to tolerate application of botanical pesticides. In such 
case, more suitable and effective control measures should be used to overcome such problems. Since these five species have not been described, it is presumed that they are possibly new species. Their morphological descriptions can therefore be used for nomenclatural system, and thus contributes to overall insect taxonomy.

\section{ACKNOWLEDGEMENT}

We are grateful to Prof.Vojtech Novotny and the helpful staff of NGBRC, Madang, PNG, for their valuable assistance during the field research. An extended appreciation goes to Prof. Yves Basset for providing research materials and resources at Wanang, Madang, PNG.

\section{REFERENCES}

[1] Abo,O. \& Ja,E. (2014) An evaluation of infestation of insect pests of flours in Benin City, Edo State, Nigeria. Journal of Applied Sciences and Environmental Management.18,487- 494.

[2] Ardakani, A. S. \& Nasserzadeh,H. (2014)First record and biology of Coffee Bean Weevil, Araecerusfasciculatus DeGeer, on pesticide plant, Meliaazedarach L. from Iran. International Journal of Biosciences.4,486-491.

[3] Barrera, J. F. (2008) Coffee Pests and their Management: El Colegio de la Frontera Sur, Tapachula, Chiapas, Mexico.

[4] Bright, D. E. (1993)The weevils of Canada and Alaska. Coleoptera: Curculionoidea, excluding Scolytidae and Curculionidae, Insects and Arachnids of Canada. Handbook Series 21, p. 217.

[5] Duke, J. A. (1993) CRC Handbook of Alternative Cash Crops. Maryland, USA: CRC Press.

[6] Eduku, A. (2014)Laboratory studies to develop cassava bait to control insect infestation of cocoa beans using Coffee Bean Weevil, Araecerusfasciculatus (De Geer) (Coleoptera: Anthribidae), as Model Species. MPhil Thesis. Faculty of Agriculture, Kwame Nkrumah University of Science and Technology.

[7] El-Sayed, M. T. (1935)The morphology, anatomy and biology of AraecerusfasciculatusDe Geer (Coleoptera: Anthribidae). Annals of Applied Biology.22, 557- 577.

[8] Holloway, B. A. (1982). Anthribidae (Insecta: Coleoptera). Fauna of New Zealand.3, 272.

[9] Jordan,K. (1894) On Anthribiclaein the museum of the Honourable Walter Rothchild. NovitatesZoologicae.1,591-651.

[10] Jordan,K. (1907) Insecta. Coleoptera.Rhynchophora.Anthribidae. In:Sharp, D., Bland ford, F. Z. S. \& Jordan, K. (eds.). BiologiaCentrali Americana.

[11] Laidlaw, M., Kitching, R, Goodall, K, Small, A. \&Stork,N.(2007) Temporal and spatial variation in an Australian tropical rainforest. Austral Ecology.32, 10-20.

[12] McAlpine, J. R., Keig, G.\&Falls,R. (1983)Climate of Papua New Guinea.CSIRO and Australian National University Press, Canberra.

[13] Mermudes, J. R. M. \&Leschen, R. A. B. (2014)AnthribidaeBillberg, 1820. In:Leschen, R. A. B \&Beutel, R. G. (eds.). Handbuch der Zoologie / Handbook of Zoology, Arthropoda, Insecta, Coleoptera.Walter De Gruyter, Berlin.

[14] Mermudes, J. R. M. (2015)A new genus and two new species of Araecerini from high elevation in the Andes with a synopsis of the tribe in South America (Coleoptera, Anthribidae, Choraginae).Zootaxa.3918,587-593.

[15] Morimoto,K. (1972)A key to the Genera of Oriental Anthribidae (Coleoptera).Bulletin of the Government Experimental Station.246, 35-54.

[16] Paijmans, K. (1976) New Guinea Vegetation. Australian National University Press, Canberra.

[17] Pascoe, F. P. (1860) On some new Anthribidae. The Annals and Magazine of Natural History.4, 327-333.

[18] Peekel, P. G. (1984) Flora of the Bismarck Archipelago for Naturalists.Lae, Papua New Guinea. Office of Forests, Division of Botany.

[19] Robinson, W. H. (2005) Handbook of urban insects and arachnids: A handbook of urban entomology. Cambridge University Press, UK.

[20] Sherman,M. and Tamashiro,M. (1955) Biology and Control of Araeceruslevipennis Jordan Coleoptera: Anthribidae).Proceedings of Hawaiian Entomological Society.16, 138-148.

[21] Valentine, B. D. (1999) A Review of Nearctic and some related Anthribidae (Coleoptera). Insecta Mundi.12, 251-296.

[22] Valentine, B. D. (2002) AnthribidaeBillberg, 1820. In:Arnett, R. H., Thomas M. C., Skelley, P. E. \& Frank, J. H. (eds.). American Beetles. Polyphaga: Scarabaeoidea through Curculionoidea. CRC Press LLC, Boca Raton, FL.

[23] Valentine, B. D. (2005) The scientific name of the coffee bean weevil and some additional bibliography (Coleoptera: Anthribidae: AraecerusSchoenherr). Insecta Mundi.19, 247-253.

[24] Whitfeld, T. J. S., Kress, W. J., Erickson, D. L. \&Weiblen, G. D. (2012) Change in community phylogenetic structure during tropical forest succession: evidence from New Guinea. Ecography.35, 821-830. 